\title{
No nitrogen fixation in the Bay of Bengal?
}

\author{
Carolin R. Löscher ${ }^{1,2}$, Wiebke Mohr ${ }^{3}$, Hermann W. Bange ${ }^{4}$, and Donald E. Canfield ${ }^{1}$ \\ ${ }^{1}$ Nordcee, Department of Biology, University of Southern Denmark, Odense, Denmark \\ ${ }^{2}$ D-IAS, University of Southern Denmark, Odense, Denmark \\ ${ }^{3}$ Max Planck Institute for Marine Microbiology, Bremen, Germany \\ ${ }^{4}$ GEOMAR Helmholtz Centre for Ocean Research Kiel, Kiel, Germany
}

Correspondence: Carolin R. Löscher (cloescher@biology.sdu.dk)

Received: 31 August 2019 - Discussion started: 10 September 2019

Revised: 4 December 2019 - Accepted: 10 January 2020 - Published: 18 February 2020

\begin{abstract}
The Bay of Bengal (BoB) has long stood as a biogeochemical enigma, with subsurface waters containing extremely low, but persistent, concentrations of oxygen in the nanomolar range which - for some, yet unconstrained, reason - are prevented from becoming anoxic. One reason for this may be the low productivity of the BoB waters due to nutrient limitation and the resulting lack of respiration of organic material at intermediate waters. Thus, the parameters determining primary production are key in understanding what prevents the BoB from developing anoxia. Primary productivity in the sunlit surface layers of tropical oceans is mostly limited by the supply of reactive nitrogen through upwelling, riverine flux, atmospheric deposition, and biological dinitrogen $\left(\mathrm{N}_{2}\right)$ fixation. In the $\mathrm{BoB}$, a stable stratification limits nutrient supply via upwelling in the open waters, and riverine or atmospheric fluxes have been shown to support only less than one-quarter of the nitrogen for primary production. This leaves a large uncertainty for most of the BoB's nitrogen input, suggesting a potential role of $\mathrm{N}_{2}$ fixation in those waters.

Here, we present a survey of $\mathrm{N}_{2}$ fixation and carbon fixation in the BoB during the winter monsoon season. We detected a community of $\mathrm{N}_{2}$ fixers comparable to other oxygen minimum zone (OMZ) regions, with only a few cyanobacterial clades and a broad diversity of non-phototrophic $\mathrm{N}_{2}$ fixers present throughout the water column (samples collected between 10 and $560 \mathrm{~m}$ water depth). While similar communities of $\mathrm{N}_{2}$ fixers were shown to actively fix $\mathrm{N}_{2}$ in other OMZs, $\mathrm{N}_{2}$ fixation rates were below the detection limit in our samples covering the water column between the deep chlorophyll maximum and the OMZ. Consistent with this, no $\mathrm{N}_{2}$ fixation signal was visible in $\delta^{15} \mathrm{~N}$ signatures. We sug-
\end{abstract}

gest that the absence of $\mathrm{N}_{2}$ fixation may be a consequence of a micronutrient limitation or of an $\mathrm{O}_{2}$ sensitivity of the OMZ diazotrophs in the BoB. Exploring how the onset of $\mathrm{N}_{2}$ fixation by cyanobacteria compared to non-phototrophic $\mathrm{N}_{2}$ fixers would impact on $\mathrm{OMZ} \mathrm{O} \mathrm{O}_{2}$ concentrations, a simple model exercise was carried out. We observed that both photic-zone-based and OMZ-based $\mathrm{N}_{2}$ fixation are very sensitive to even minimal changes in water column stratification, with stronger mixing increasing organic matter production and export, which can exhaust remaining $\mathrm{O}_{2}$ traces in the BoB.

\section{Introduction}

Primary production in large areas of the surface ocean is limited by the availability of fixed nitrogen (Moore et al., 2013). This deficiency in nitrogen creates a niche for dinitrogen $\left(\mathrm{N}_{2}\right)$ fixation, an energy-costly process carried out only by certain prokaryotes, also referred to as diazotrophs, which are phylogenetically highly diverse. $\mathrm{N}_{2}$ fixation in the ocean has been described quantitatively as most important in the oligotrophic surface waters of the subtropical gyres (Sohm et al., 2011; Luo et al., 2012; Wang et al., 2019) where cyanobacterial $\mathrm{N}_{2}$ fixers dominate. Over the last decade, the development of novel molecular tools revealed that non-cyanobacterial $\mathrm{N}_{2}$ fixers are widely distributed throughout ocean waters (Farnelid et al., 2011, 2013; Fernandez et al., 2011; Luo et al., 2012; Riemann et al., 2010; Zehr et al., 1998) and sediments (Fulweiler et al., 2007; Andersson et al., 2014; Bertics et al., 2013; Gier et al., 2017, 2016). Their quantitative importance for global $\mathrm{N}_{2}$ fixation, however, is not yet clear. In oxy- 
gen minimum zones (OMZs) of the eastern tropical North and South Pacific Ocean, hypoxic basins in the San Pedro Ocean Time-series and the Santa Monica Bay Observatory in the Southern California Bight, and the Arabian Sea, those $\mathrm{N}_{2}$ fixers form a unique community consisting of different clades of proteobacteria, clostridia, spirochaetes, chlorobia, and methanogenic archaea (Christiansen and Loescher, 2019; Dekaezemacker et al., 2013; Fernandez et al., 2011; Gaby et al., 2018; Gier et al., 2017; Goebel et al., 2010; Halm et al., 2012; Hamersley et al., 2011; Jayakumar et al., 2012, 2017; Löscher et al., 2014). In contrast, cyanobacterial $\mathrm{N}_{2}$ fixers and diatom-diazotroph associations (DDAs), which are commonly considered the most important $\mathrm{N}_{2}$ fixers in the surface ocean, were either absent or were detected only in low abundances in OMZs (Turk-Kubo et al., 2014; White et al., 2013; Jayakumar et al., 2012). Both the presence of diazotrophs clustering with proteobacteria, clostridia, spirochaetes, chlorobia, and methanogenic archaea and the underrepresentation of cyanobacterial and DDA $\mathrm{N}_{2}$ fixers could thus be considered characteristic for OMZ environments.

Nutrient stoichiometry and model predictions (Deutsch et al., 2007) suggest that oxygen-deficient waters are a potentially important niche for $\mathrm{N}_{2}$ fixation. Based on this suggestion, several studies have focused on $\mathrm{N}_{2}$ fixation in the large and persistent OMZ of the eastern tropical South Pacific. In this region $\mathrm{N}_{2}$ fixation rates vary, however, with maximum rates of $840 \mu \mathrm{molN} \mathrm{m}^{-2} \mathrm{~d}^{-1}$ detected in nitrogenous sulfidic waters off the coast of Peru (Löscher et al., 2014) and $117 \mu \mathrm{mol} \mathrm{N} \mathrm{m}{ }^{-2} \mathrm{~d}^{-1}$ in the oxygen-depleted zone (Bonnet et al., 2013). Low $\mathrm{N}_{2}$ fixation rates close to the detection limit were reported from the same area (Chang et al., 2019); another set of $\mathrm{N}_{2}$ fixation rates estimated from sediment trap analyses were in the range of $0-23 \mu \mathrm{mol} \mathrm{N} \mathrm{m}{ }^{-2} \mathrm{~d}^{-1}$ (Knapp et al., 2016). Taken together, these rates suggest either a strong temporal variation or spatial patchiness. A similar variation in $\mathrm{N}_{2}$ fixation rates was described for the eastern tropical North Pacific, ranging from close to the detection limit in the OMZ (Jayakumar et al., 2017) up to $795 \mu \mathrm{mol} \mathrm{N} \mathrm{m}{ }^{-2} \mathrm{~d}^{-1}$ in episodic diazotroph blooms (White et al., 2013). This apparent temporal or spatial variation in $\mathrm{N}_{2}$ fixation rates may originate from unresolved environmental controls on $\mathrm{N}_{2}$ fixation and makes it difficult to quantify $\mathrm{N}_{2}$ fixation in OMZ waters.

The Bay of Bengal $(\mathrm{BoB})$ is a region with a strong seasonality driven by the Asian monsoon system. Massive rainfall and river discharge with maximum freshwater inputs in September (e.g., Mahadevan, 2016) cause a considerable lowering of surface water salinity during and after the monsoons throughout the whole basin (Subramanian, 1993). This, together with increased surface water temperatures, leads to intensive and persistent stratification of the water column (Kumar et al., 2004), restricting nutrient fluxes to the surface from below and promoting a strong OMZ (McCreary et al., 2013; Paulmier and Ruiz-Pinto, 2009; Sarma,
2002) with minimum oxygen $\left(\mathrm{O}_{2}\right)$ concentrations in the lower nanomolar range (Bristow et al., 2017).

The potential importance of $\mathrm{N}_{2}$ fixation in the $\mathrm{BoB}$ can be derived from a simple $\mathrm{N}$ budget estimate with an overall $\mathrm{N}$ loss of $7.9 \pm 0.6 \mathrm{Tg} \mathrm{Nyr}^{-1}$ and $\mathrm{N}$ sources other than $\mathrm{N}_{2}$ fixation of $3.15 \pm 2.25 \mathrm{Tg} \mathrm{Nyr}^{-1}$ (Table 1 - data from Naqvi, 2008; Naqvi et al., 2010; Bristow et al., 2017; Singh et al., 2012; Krishna et al., 2016; Srinivas and Sarin, 2013; Suntharalingam et al., 2019). This implies a deficit of $4.7 \pm$ $2.4 \mathrm{Tg} \mathrm{Nyr}^{-1}$ within the given range of uncertainty, indicating the potential importance of $\mathrm{N}_{2}$ fixation, assuming a coupling of nitrogen loss and $\mathrm{N}_{2}$ fixation as proposed by Deutsch et al. (2007). Naqui et al. (2010) proposed $\mathrm{N}_{2}$ fixation to contribute $1 \mathrm{TgN} \mathrm{yr}^{-1}$ in the $\mathrm{BoB}$, while Srinivas and Sarin (2013) interpolated a contribution of $0.6-4 \mathrm{Tg} \mathrm{Nyr}^{-1}$ from phosphate availability. Measurements of $\mathrm{N}_{2}$ fixation rates from the BoB are not available, and isotope analysis of sediment trap samples indeed suggests that the $B o B$ is a site of active $\mathrm{N}_{2}$ fixation. The composition of the organic material produced in BoB surface waters is characterized by a high portion of biogenic opal $(20 \%)$ and a low $\delta^{15} \mathrm{~N}$ nitrate signal (3.2\%o-5\%o; Gaye-Haake et al., 2005). This points towards a production of a considerable part of organic matter produced by diatoms in symbiotic association with or in close proximity to diazotrophs (Subramaniam et al., 2008). Only few studies report the presence of diazotrophs including Trichodesmium in the BoB (Wu et al., 2019; Shetye et al., 2013; Sahu et al., 2017; Jyothibabu et al., 2006; Mulholland and Capone, 2009), with only one of them using a functional gene approach.

To investigate the diazotrophic community and to quantify $\mathrm{N}_{2}$ and carbon fixation in the BoB OMZ, we used a combination of gene sequencing and quantification, rate measurements, isotope tracing, and box modeling.

\section{Methods}

\subsection{Geochemical sampling}

Samples were collected from the top $500 \mathrm{~m}$ of the water column during the SK-308 cruise with the ORV Sagar Kanya to the $\mathrm{BoB}$ during the winter monsoon between 24 January and 3 February 2014. Seawater samples were collected using 5 and $30 \mathrm{~L}$ Niskin bottles on a CTD rosette equipped with a Sea-Bird SBE 43 oxygen sensor and a Wet Labs ECOAFL/FL chlorophyll sensor as previously described in Bristow et al. (2017). To resolve oxygen dynamics below the SeaBird sensor's detection limit, a STOX (switchable trace oxygen) amperometric oxygen sensor was used (Revsbech et al., 2009), which had a detection limit of $7-12 \mathrm{nmolL}^{-1}$ during this sampling campaign (Bristow et al., 2017). Nutrients, including nitrate, nitrite, and phosphate, were determined according to Grasshoff et al. (1999). 
Table 1. Nitrogen fluxes in the $\mathrm{BoB}\left(\mathrm{Tg} \mathrm{Nyr}^{-1}\right)$. $\mathrm{N}$ loss fluxes are given in black, and $\mathrm{N}$ sources are given in gray. DIN: dissolved inorganic nitrogen. PON: particulate organic nitrogen. IO: Indian Ocean. $\mathrm{N}_{2}$ loss by denitrification was excluded by Bristow et al. (2017). Naqvi et al. (2010) reported possible $\mathrm{N}$ loss to the atmosphere in the form of $\mathrm{N}_{2} \mathrm{O}$.

\begin{tabular}{lrl}
\hline & Flux $\left(\mathrm{TgN} \mathrm{yr}^{-1}\right)$ & Reference \\
\hline Net exchange with the IO & 3.3 & Naqvi et al. (2010) \\
Sedimentary denitrification & $3-4.1$ & Naqvi (2008), Naqvi et al. (2010) \\
PON burial & 1 & Naqvi et al. (2010) \\
Water column N loss to the atmosphere & $0-0.07$ & Naqvi et al. (2010), Bristow et al. (2017) \\
Atmospheric deposition & $0.5-1.6$ & Naqvi et al. (2010), Singh et al. (2012), Suntharalingam et al. (2019) \\
Riverine and land input & $0.4-4$ & Naqvi et al. (2010), Singh et al. (2012), Krishna et al. (2016) \\
$\mathrm{N}_{2}$ fixation & $0.6-11.3$ & Naqvi et al. (2010), Srinivas and Sarin (2013) \\
\hline
\end{tabular}

\section{$2.2 \quad \mathrm{~N}_{2}-\mathrm{C}$ fixation rate measurements}

Seawater was collected from depth between 60 and $280 \mathrm{~m}$ water depth. Water was taken from Niskin bottles and filled into $2.4 \mathrm{~L}$ glass bottles or $2.8 \mathrm{~L}$ polycarbonate bottles for (near-)anoxic and all other (oxic) waters, respectively. Bottles were capped with black rubber stoppers (anoxic waters) or Teflon-coated butyl rubber septa (oxic waters). Incubations were performed with the method developed by Mohr et al. (2010), as described in Grosskopf et al. (2012). Batches of ${ }^{15} \mathrm{~N}_{2}$-gas-enriched (Cambridge Isotopes, USA) water were prepared with degassed water from two to three of the six sampling depths. Each incubation bottle was supplemented with $50 \mathrm{~mL}$ of the ${ }^{15} \mathrm{~N}_{2}$-enriched seawater. Discrete samples for the measurement of the ${ }^{15} \mathrm{~N}_{2}$ concentration were taken from each incubation bottle and were measured by membrane-inlet mass spectrometry (MIMS). Final ${ }^{15} \mathrm{~N}_{2}$ enrichments were on average 1.65 at. $\%{ }^{15} \mathrm{~N}$. For carbon fixation measurements, $\mathrm{NaH}^{13} \mathrm{CO}_{3}$ was dissolved in sterile Milli-Q water $(1 \mathrm{~g} / 117 \mathrm{~mL})$, and $5 \mathrm{~mL}$ was added to each incubation ( $\sim 8$ at. \% final, based on total DIC of $2.2 \mathrm{mM})$. Bottles with water from the upper two depths were kept in surface seawater-cooled on-deck incubators. Bottles from the lower depths were incubated at $13-15^{\circ} \mathrm{C}$ in the dark. Incubations were stopped after approximately $24 \mathrm{~h}$ (samples with less than $20 \mathrm{~h}$ incubation time were excluded from our analysis). Volumes between 2.1 and $2.7 \mathrm{~L}$ of seawater were filtered onto pre-combusted $\left(450^{\circ} \mathrm{C} ; 4-6 \mathrm{~h}\right) 25 \mathrm{~mm}$ diameter GF/F filters (Whatman, GE Healthcare, Chalfont St Giles, UK) under a gentle vacuum (200 mbar). Filters were either frozen at $-20^{\circ} \mathrm{C}$ and oven dried prior to processing or oven dried $\left(50^{\circ} \mathrm{C}\right)$ directly for $24 \mathrm{~h}$ and stored dry until analysis. Untreated seawater was filtered and prepared as described above to obtain background natural abundance values. For elemental and isotopic analysis, GF/F filters were acidified over fuming $\mathrm{HCl}$ overnight in a desiccator to remove inorganic C. Filters were then oven dried for $2 \mathrm{~h}$ at $50^{\circ} \mathrm{C}$ and pelletized in tin cups. Samples for particulate organic carbon and nitrogen (POC and $\mathrm{PON}$ ) and $\mathrm{C}$ and $\mathrm{N}$ isotopic composition were analyzed on an Elemental Analyzer Flash EA 1112 series (Thermo Fisher) coupled to a continuous-flow isotope ratio mass spectrometer (Finnigan Delta Plus XP, Thermo Fisher). Table 2 summarizes $\mathrm{N}_{2}$, and $\mathrm{C}$ fixation rate measurements are given in the Supplement. Datasets were deposited on PANGAEA.

\subsection{Molecular methods}

Nucleic acid samples were collected at stations 1, 4, and 5 (Fig. 1) from water depths between 10 and $560 \mathrm{~m}$. Between 5 and $27 \mathrm{~L}$ of seawater was filtered in two size fractions (3 and $0.22 \mu \mathrm{m}$ pore size; Supor PES Membrane Disc Filters; Pall, Portsmouth, UK), and exact filtration volumes were recorded. Filters were stored in $2.7 \mathrm{~mL}$ sucrose lysis buffer at $-20^{\circ} \mathrm{C}$.

DNA was extracted using an established protocol based on a phenol and chloroform extraction (Giovannoni et al., 1996). The quality and concentration of the purified DNA was checked spectrophotometrically and using the Quant-iT PicoGreen dsDNA kit (Invitrogen, Carlsbad, USA).

A metagenome from the deep chlorophyll maximum (DCM; $84 \mathrm{~m}$ water depth) at station 4 was sequenced with Illumina HiSeq using a $2 \mathrm{bp} \times 125 \mathrm{bp}$ read length on a Nextera XT library at the Institute of Clinical Molecular Biology (IKMB) at Kiel University, Germany. Sequencing resulted in $321 \mathrm{Mb}$. Sequences were analyzed using the MetaPathways pipeline (Konwar et al., 2013), a modular annotation and analysis pipeline for predicting diversity and metabolic interaction from environmental sequences consisting of a quality control, an open reading frame prediction and annotation, diversity analysis, and environmental pathway reconstruction. Phylogenetic identification of operational taxonomic units (OTUs) was derived via a comparison with the RefSeq and Greengenes databases (DeSantis et al., 2006). After a quality check, 6454 sequences of ribosomal RNA were identified, 622286 sequences $(27.56 \%)$ of proteins with known functions were identified, and 1628841 sequences (72.15\%) were predicted proteins with an unknown function.

nifH gene amplification was performed using a nested polymerase chain reaction (PCR) protocol (Zehr et al., 1998). PCRs were performed using the GoTaq kit (Promega, Fitch- 
Table 2. $\mathrm{CO}_{2}$ and $\mathrm{N}_{2}$ fixation rates based on triplicate measurements at stations $1\left(17.9970^{\circ} \mathrm{N}, 88.9968^{\circ} \mathrm{E}\right), 4\left(16.9828^{\circ} \mathrm{N}, 89.2063^{\circ} \mathrm{E}\right)$, and $5\left(17.2075^{\circ} \mathrm{N}, 89.4282^{\circ} \mathrm{E}\right) . \mathrm{N}_{2}$ fixation was only measurable in two individual samples but only in one out of three technical replicates.

\begin{tabular}{lrrrrr}
\hline $\begin{array}{l}\text { Station } \\
\text { no. }\end{array}$ & $\begin{array}{r}\text { Incubation } \\
\text { depth }\end{array}$ & $\begin{array}{r}\mathrm{CO}_{2} \text { fixation } \\
\left(\mathrm{nmol} \mathrm{L}^{-1} \mathrm{~d}^{-1}\right)\end{array}$ & $\mathrm{SD}$ & $\begin{array}{r}\mathrm{N}_{2} \text { fixation } \\
\left(\mathrm{nmolL}^{-1} \mathrm{~d}^{-1}\right)\end{array}$ & $\mathrm{SD}$ \\
\hline 1 & 67 & 460.1 & 14.0 & 0.0 & 0.0 \\
1 & 106 & 186.2 & 174.7 & 0.0 & 0.0 \\
1 & 112 & 0.0 & 0.0 & 0.0 & 0.0 \\
1 & 128 & 8.8 & 2.6 & 17.4 & 8.2 \\
1 & 169 & 4.8 & 0.2 & 0.0 & 0.0 \\
1 & 253 & 2.0 & 2.9 & 0.0 & 0.0 \\
4 & 60 & 286.1 & 270.2 & 0.0 & 0.0 \\
4 & 112 & 50.6 & 4.1 & 0.0 & 0.0 \\
4 & 145 & 0.0 & 0.0 & 0.0 & 0.0 \\
4 & 176 & 2.4 & 2.4 & 0.0 & 0.0 \\
4 & 213 & 3.2 & 2.2 & 1.0 & 0.5 \\
4 & 265 & 10.2 & 2.9 & 0.0 & 0.0 \\
5 & 60 & 1855.0 & 157.6 & 0.0 & 0.0 \\
5 & 111 & 109.3 & 5.8 & 0.0 & 0.0 \\
5 & 122 & 41.7 & 1.2 & 0.0 & 0.0 \\
5 & 157 & 37.8 & 3.8 & 0.0 & 0.0 \\
5 & 195 & 37.7 & 4.5 & 0.0 & 0.0 \\
5 & 280 & 56.1 & 12.4 & 0.0 & 0.0 \\
\hline
\end{tabular}

burg, USA), adding 1 additional microliter of bovine serum albumin (BSA; $20 \mathrm{mg} \mathrm{mL}^{-1}$; Fermentas, Waltham, USA). The Topo TA Cloning ${ }^{\circledR}$ kit (Invitrogen, Carlsbad, USA) was used for cloning of PCR amplicons, according to the manufacturer's protocol. Sanger sequencing (340 nifH sequences) was performed by the Institute of Clinical Molecular Biology, Kiel, Germany. Negative controls were performed using the PCR mixture as described without template DNA; no amplification was detected. Samples from the particulate fraction $>3 \mu \mathrm{m}$ were consistently negative for nifH gene copies and were thus not further investigated. Sequences were ClustalW aligned in MEGA 7 (Kumar et al., 2016), and a maximum-likelihood tree was constructed on a 321 base pair fragment. Reference sequences were obtained using BlastX on the NCBI database. Sequences were submitted to GenBank (submission ID 2245434). The metagenome was submitted to the NCBI's sequence read archive (accession number SRR9696254).

Quantitative real-time PCRs for nifH were performed using the cluster-specific TaqMan probe qPCRS as described in Löscher et al. (2014), with primers, probes, environmental standards, and PCR conditions as presented in the text. Samples were run in duplicates on a Bio-Rad qPCR machine (Bio-Rad, Hercules, USA).

\subsection{Box model exercise}

We used a simplistic five-box representation of an upwelling system with a deep- and intermediate-water iron source, with primary and export production as well as respiration derived from the original models (Canfield, 2006; Boyle et al., 2013).
The model was used to distinguish a $\mathrm{N}_{2}$ fixation state of the $\mathrm{BoB}$ and a non- $\mathrm{N}_{2}$ fixation state with primary production driven by recycled dissolved nitrogen compounds. In contrast to the previous model versions, we applied a non-Redfieldbased $\mathrm{N}_{2}$ fixation scenario. Ammonia concentrations were set to zero in all boxes, in accordance with our direct measurements. Fe concentrations were set to $0.1 \mu \mathrm{molL}^{-1}$ in the deep- and intermediate-water boxes and $0.00044 \mu \mathrm{mol} \mathrm{L}^{-1}$ in the productive zone (Grand et al., 2015a, b). Oxygen concentrations were adjusted to our measurements, with 220, 0.02, and $50 \mu \mathrm{mol} \mathrm{L}^{-1}$ in the surface (corresponding to the upper $60 \mathrm{~m}$ of the water column), OMZ, and deep water, respectively (Bristow et al., 2017). Phosphate and nitrate concentrations were taken from our measurements, with phosphate concentrations of $0,2.7$, and $2.5 \mu \mathrm{mol} \mathrm{L}^{-1}$ in the surface, OMZ, and deep boxes, respectively, and oxidized nitrogen compounds (nitrate + nitrite) at a concentration of 0,38 , and $35 \mu \mathrm{molL}^{-1}$ in the surface, intermediate, and deep boxes, respectively. Further information on the model stoichiometry is given in the Supplement.

\section{Results and discussion}

We explored the diversity, distribution, and activity of $\mathrm{N}_{2-}$ fixing microbes and carbon fixers in the $\mathrm{OMZ}$ of the northern BoB during the northeast monsoon in January 2014. During the time of the cruise, low sea surface temperatures (SSTs; surface waters refer to water depths shallower than the mixed layer depth of $60 \mathrm{~m}$ ) and low surface water salinity reaching from the coasts of India, Bangladesh, and Myanmar south- 

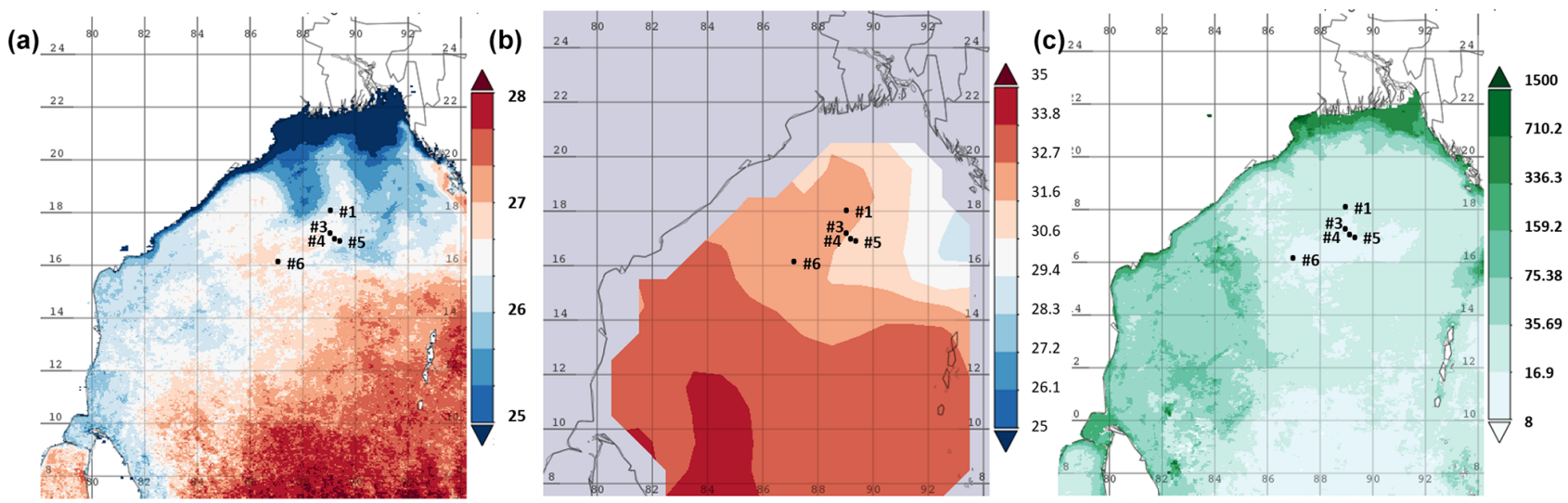

(d)

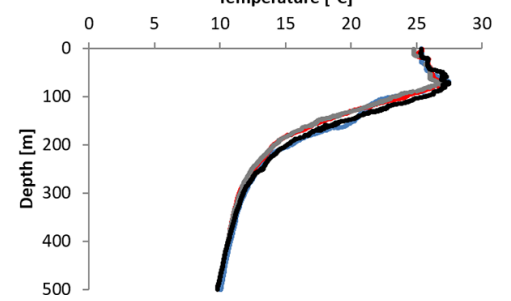

(e)

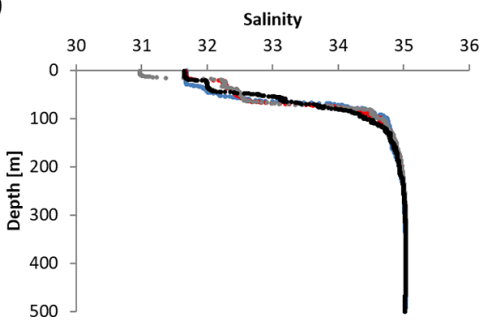

(f)

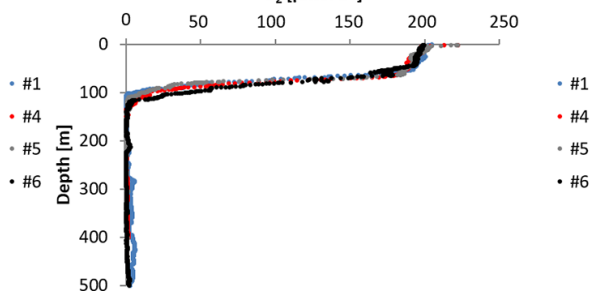

Figure 1. Time-averaged maps from 15 January 2014 to 15 February 2014 of (a) sea surface temperature (SST in ${ }^{\circ} \mathrm{C}$; night only; eight daily, $4 \mathrm{~km}$ resolution obtained from MODIS-Aqua; https://giovanni.gsfc.nasa.gov, last access: 29 August 2019), (b) sea surface salinity, and (c) chlorophyll $a$ concentration in $10^{-2} \mathrm{mg} \mathrm{m}^{-3}$ (note the log scale; eight daily, $4 \mathrm{~km}$ resolution obtained from MODIS-Aqua; https: //giovanni.gsfc.nasa.gov). (d) CTD data-based water temperature in ${ }^{\circ} \mathrm{C}$, and (e) salinity at the cruise stations. (f) $\mathrm{O}_{2}$ (in $\mu$ molL $\mathrm{L}^{-1}$ ) over the top $500 \mathrm{~m}$ of the water column, with data from Bristow et al. (2017).

wards to approximately $16^{\circ} \mathrm{N}$ were present (Fig. 1a, b). At the coast, this low-salinity and low-SST plume co-occurred with increased chlorophyll concentrations (Fig. 1c), thus suggesting a stimulation of primary production by waters possibly of riverine origin (Fig. 1c). This is in line with earlier suggestions of riverine-nutrient runoff promoting primary production close to the shelf, where nutrients are consumed rapidly, thus preventing their offshore transport (Kumar et al., 2004; Singh et al., 2012; Singh and Ramesh, 2011; Krishna et al., 2016). Chlorophyll concentrations in the BoB during the time of the cruise detected via satellite monitoring ranged between $0.08 \mathrm{mg} \mathrm{m}^{-3}$ in open waters and $15 \mathrm{mg} \mathrm{m}^{-3}$ at the northern coast and were consistent with previous in situ measurements during low productivity periods in the $\mathrm{BoB}$ (Kumar et al., 2010).

The sampling stations were located offshore in the central $\mathrm{BoB}$ (Fig. 1), where waters were strongly stratified with low sea surface salinity but warmer SST compared to the coast and a steep oxycline reaching $\mathrm{O}_{2}$ concentrations close to anoxia at around $100 \mathrm{~m}$ water depth. No in situ chlorophyll measurements are available from the cruise, but a fluorescence sensor attached to the CTD showed a maximum of up to $0.8 \mathrm{mg} \mathrm{m}^{-3}$ between 32 and $90 \mathrm{~m}$ water depth (Fig. 2). Satellite-derived chlorophyll concentrations in the coastal $\mathrm{BoB}$ were in the range from 0.08 to
$0.35 \mathrm{mg} \mathrm{m}^{-3}$, slightly higher than in a previous study of this region $\left(0.06 \mathrm{mg} \mathrm{m}^{-3}\right.$; Kumar et al., 2002). Carbon fixation rates ranged between 286 and $1855 \mathrm{nmolCL}^{-1} \mathrm{~d}^{-1}$ at the depth of the DCM (Fig. 2, $84 \mathrm{~m}$ ); however, our rate measurements did not cover the water column above $60 \mathrm{~m}$ water depth, where rates may have been higher. Consistent with previous descriptions of primary producers at our study site (Loisel et al., 2013) and with satellite imaging (Fig. S1 in the Supplement), we identified cyanobacteria related to Synechococcus and Prochlorococcus as the most abundant primary producers in our metagenome from the BoB DCM, accounting for $3.3 \%$ of OTUs, while eukaryotic phytoplankton accounted for only $0.3 \%$ of OTUs (Table S1 in the Supplement).

Similar to chlorophyll, particulate organic carbon (Table S2; see also Fig. S2 for a distribution of POC in the $\mathrm{BoB})$ concentrations were low, ranging between 4.96 and $7.84 \mu \mathrm{mol} \mathrm{CL}^{-1}$ in surface waters and resulting in an average POC : chlorophyll ratio of $68: 1$ to $115: 1$ at the depth of the DCM (Fig. 1). This ratio is comparable to POC : chlorophyll ratios reported from cyanobacteria-dominated communities (74: 1 to 126 : 1; e.g., Lorenzoni et al., 2015; Sathyendranath et al., 2009), but it is higher compared to other OMZ regions (e.g., $50: 1$ in the eastern tropical South Pacific; Chavez and Messié, 2009; Chavez et al., 1996). Similarly, carbon fixa- 
(a)
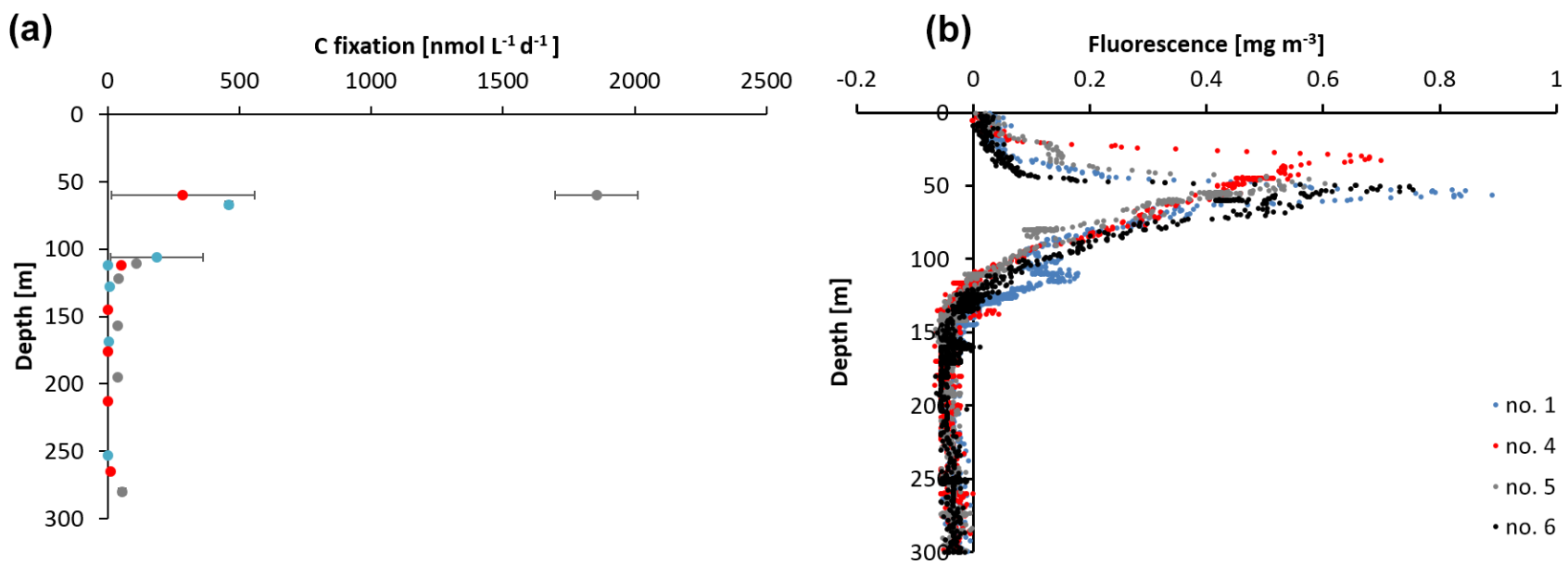

Figure 2. (a) Carbon fixation rates at stations 1, 4, and 5 and (b) sensor-based fluorescence measurements from station 1, 4, 5, and 6 .

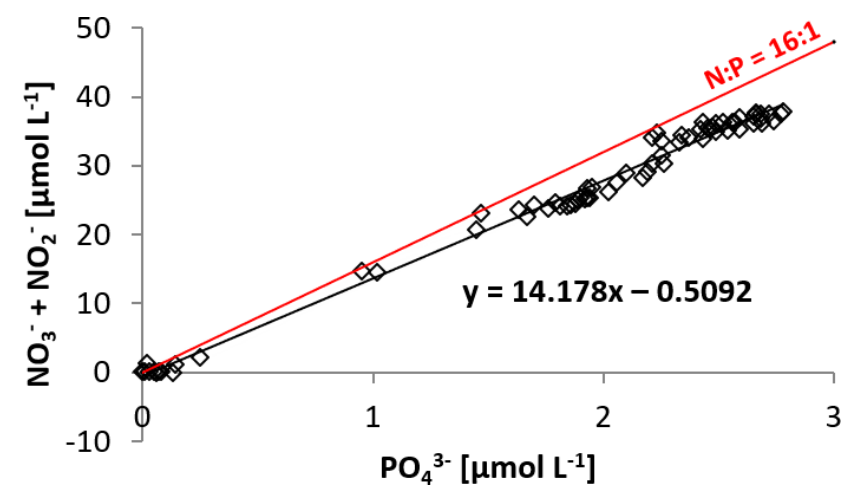

Figure 3. $\mathrm{N}: \mathrm{P}$ ratio at station $1,4,5$, and 6 , with the Redfield ratio of $\mathrm{N}: \mathrm{P}=16: 1$ indicated with a red line. The negative intercept of the trend line indicates a deficit in dissolved inorganic nitrogen.

tion rates were 1-2 orders of magnitude lower compared to the Arabian Sea, the tropical South Pacific, and the tropical Atlantic (e.g., Longhurst et al., 1995). While our POC concentrations from DCM are 1 order of magnitude higher than the satellite-derived POC estimates (Fig. S2) from surface waters, indicating that $\mathrm{POC}$ and primary production in surface waters was not higher than in the DCM, it must be noted that our measurements did not cover the entire mixed layer and are thus likely a rather conservative minimum estimate.

\section{1 $\mathrm{N}_{2}$ fixation in the upper water column and the oxycline}

Based on the ratio of dissolved inorganic nitrogen $\left(\mathrm{NO}_{3}^{-}+\right.$ $\mathrm{NO}_{2}^{-}$) to phosphate $\left(\mathrm{PO}_{4}^{3-}\right)$, which has a negative intercept with the $y$ axis (Fig. 3; Benitez-Nelson, 2000), primary production in $\mathrm{BoB}$ waters appeared nitrogen limited during the cruise, assuming Redfield stoichiometry. This nitrogen limitation would be expected to create a niche for $\mathrm{N}_{2}$ fixation, but except for two samples for which in both cases only one out of three technical replicates showed an isotope enrichment, $\mathrm{N}_{2}$ fixation rates were below the detection limit (Table 2). In this context, it is important to note that our rate measurements only cover water depths between 60 and $280 \mathrm{~m}$, thus excluding the upper part of the euphotic zone. However, the absence of $\mathrm{N}_{2}$ fixation even in waters shallower than $60 \mathrm{~m}$ is consistent with the observed $\delta^{15} \mathrm{~N}$ signatures (data available from 3 to $2300 \mathrm{~m}$ water depth; Bristow et al., 2017) of both the nitrate and the particulate organic nitrogen (PON) pool. $\delta^{15} \mathrm{~N}$ signatures were only slightly decreased in the top $100 \mathrm{~m}$ of the water column to $5 \%$ - $8 \%$ o (Fig. S3), thus not speaking for the presence of active $\mathrm{N}_{2}$ fixation which would be expected to create substantially lighter $\delta^{15} \mathrm{~N}$ signatures of $-2 \%$ - $2 \%$ (e.g., Dähnke and Thamdrup, 2013). Several clusters of $\mathrm{N}_{2}$-fixing microbes were, however, identified by screening for the key functional marker gene nifH (Fig. 4). Only a few nifH sequences were associated with cyanobacteria commonly abundant in ocean surface waters, even in the euphotic zone at $10 \mathrm{~m}$ water depth. This pattern seems to be typical for OMZ areas (Fernandez et al., 2011; Jayakumar et al., 2012; Löscher et al., 2014) and for the eastern Indian Ocean (Wu et al., 2019), where cyanobacterial nifH sequences are also rare. Similar to earlier studies, which identified Trichodesmium in BoB surface waters (Bhaskar et al., 2007; Hegde, 2010; Wu et al., 2019), we detected nifH copies related to Trichodesmium in our samples, both by sequencing and by qPCR (Fig. 4; Table S3). These sequences clustered closely to Trichodesmium and nifH previously recovered from the Arabian Sea (Jayakumar et al., 2012; Mazard et al., 2004), where those $\mathrm{N}_{2}$ fixers were found in low abundances, but possibly actively fixing $\mathrm{N}_{2}$, as indicated by nifH presence in a cDNA library. No sequences related to the different groups of unicellular cyanobacterial diazotrophs (UCYN-A, UCYN-B, or UCYN-C; Zehr et al., 2001) were present in our nifH dataset. UCYN-A and UCYN-B have previously been found in the Arabian Sea, but 


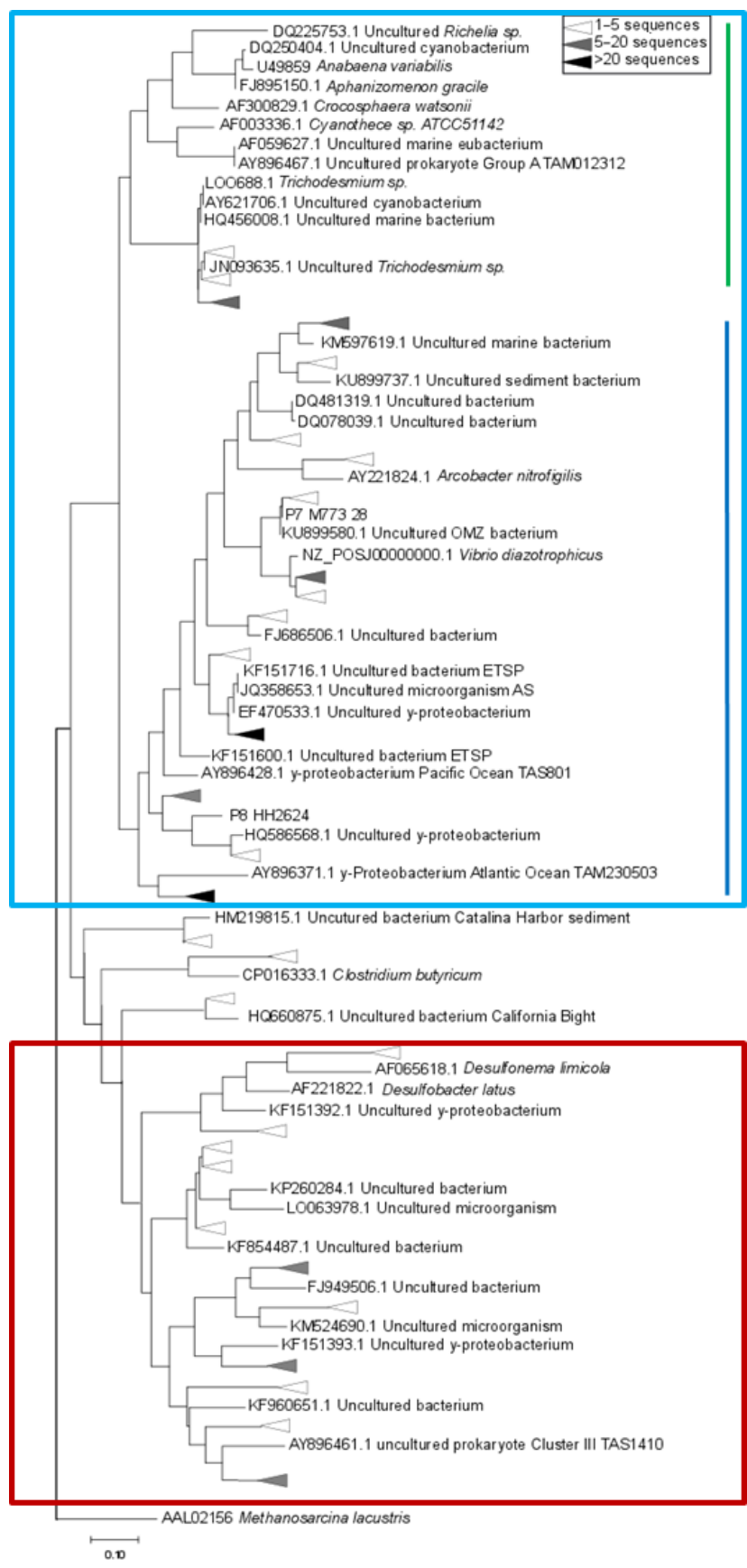

Figure 4. Maximum-likelihood tree of a $321 \mathrm{bp}$ fragment of the nifH gene. Clusters identified by Sanger sequencing are indicated with triangles, with colors denoting the sequence abundances in our dataset. The light blue box indicates Cluster I sequences, including cyanobacteria (green line) and proteobacteria (blue line). Cluster III sequences are indicated with a red box.

only at oligotrophic stations with warm water temperatures $>30^{\circ} \mathrm{C}$ (Mazard et al., 2004). While UCYN-A may occur at temperatures below $25^{\circ} \mathrm{C}$, Trichodesmium and UCYN-B may be limited by the water temperatures at our sampling stations, which were possibly too low, at around $25^{\circ} \mathrm{C}$. Tri- chodesmium is usually abundant in high-iron-input regions such as the tropical Atlantic Ocean (Martínez-Pérez et al., 2016). The absence of Trichodesmium and other cyanobacterial $\mathrm{N}_{2}$ fixers may thus also result from an insufficient iron source (Moore et al., 2013). Additionally, light limitation due to severe atmospheric pollution (known as the South Asian brown cloud) which lasts over the BoB from November to May (e.g., Ramanathan et al., 2007) may influence the distribution of cyanobacteria in the BoB (Kumar et al., 2010). While earlier studies also detected Chaetoceros (Bhaskar et al., 2007; Hegde, 2010; Wu et al., 2019), a diatom known to live in association with diazotrophs, no diatom-associated $\mathrm{N}_{2}$ fixers could be identified from our sequences. Thus our data do not directly support previous suggestions of those specific diazotrophs producing low $\delta^{15} \mathrm{~N}$ nitrate signatures along with high opal concentrations previously detected in sediment trap samples (Gaye-Haake et al., 2005).

\section{2 $\mathrm{N}_{2}$ fixation in the $\mathrm{OMZ}$}

In the cruise area, we detected again the genetic potential for $\mathrm{N}_{2}$ fixation, but $\mathrm{N}_{2}$ fixation rates were below the detection limit and $\delta^{15} \mathrm{~N}$ signatures of nitrate and PON indicated nitrogen loss instead of $\mathrm{N}_{2}$ fixation (Fig. S3). The community of $\mathrm{N}_{2}$ fixers in the BoB consisted mostly of the nonphototrophic, proteobacterial representatives of nifH - clusters I and III (Fig. 4), most of them related to previously identified OMZ diazotrophs (Fernandez et al., 2011; Jayakumar et al., 2012; Löscher et al., 2014).

A statistical comparison of BoB nifH sequences with OMZ diazotroph communities from the Arabian Sea, the eastern tropical South Pacific (ETSP), eastern tropical North Pacific (ETNP), and hypoxic basins in California Bay revealed a strong similarity, suggesting that certain diazotrophs are characteristic for OMZs (Fig. 5). Those typical OMZ clusters include uncultured $\gamma-, \delta$-, and $\varepsilon$-proteobacteria and clostridia. Only one cluster was uniquely represented in the $\mathrm{BoB}$ and absent from the other OMZ datasets, with only three individual sequences related to Azotobacter chroococum. Another difference between the BoB and the other OMZ diazotroph communities was the composition of Cluster IV nifH sequences, which are present but cluster in different groups as compared to, for instance, the Arabian Sea Cluster IV community. It is, however, unlikely that Cluster IV diazotrophs are important for $\mathrm{N}_{2}$ fixation in the $\mathrm{BoB}$ or other OMZs because they were never shown to be transcribed (Fernandez et al., 2011; Jayakumar et al., 2012; Löscher et al., 2014), and Cluster IV nif is generally considered to encode non-functional nif or paralogous sequences (Gaby and Buckley, 2014; Angel et al., 2018). In addition, the presence of Cluster IV nifH sequences has previously been ascribed to PCR contamination (Zehr et al., 2003). Thus, the importance of this cluster for $\mathrm{N}_{2}$ fixation in OMZs is generally debatable, and the different composition of the Cluster IV diazotroph 


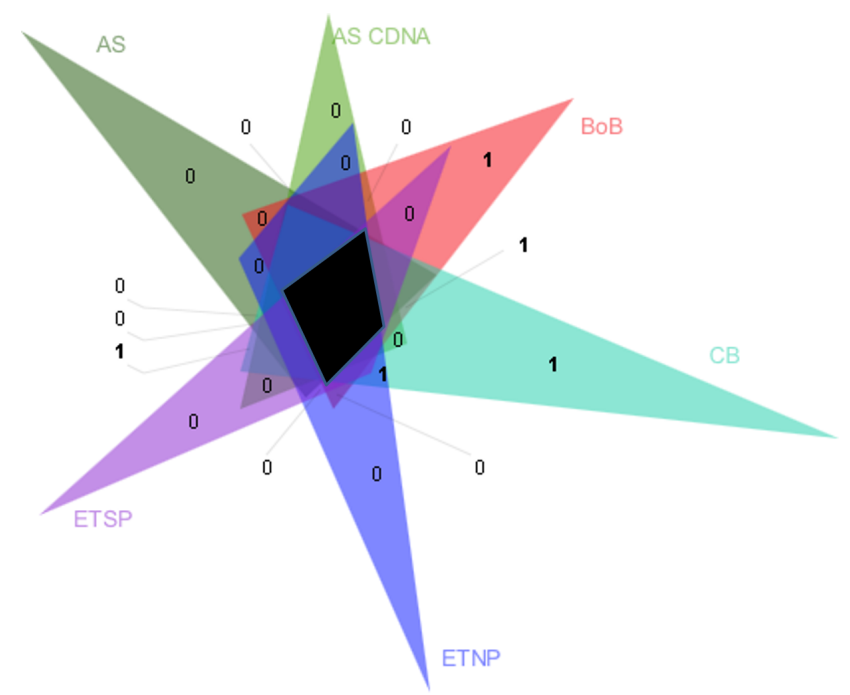

Figure 5. Venn diagram of nifH clusters present in Arabian Sea DNA libraries (AS) and in cDNA libraries (AS cDNA) and clusters identified in the $\mathrm{BoB}, \mathrm{O}_{2}$-depleted basins of the Californian Bay (CB), the eastern tropical North Pacific (ETNP), and the eastern tropical South Pacific (ETSP). Clusters as depicted by triangles in Fig. S6 were collapsed based on a $98 \%$ identity. The black area shows the clusters present in all OMZs. Numbers indicate the individual clusters in fields which would otherwise appear unproportionally large.

community likely .does not explain the absence of $\mathrm{N}_{2}$ fixation in the BoB.

While diazotroph communities highly similar to the identified $\mathrm{BoB}$ diazotrophs promote active $\mathrm{N}_{2}$ fixation in other $\mathrm{OMZ}$ waters, we have no consistent indication for $\mathrm{N}_{2}$ fixation in the $\mathrm{BoB}$ (Table 2). One explanation for the absence of $\mathrm{N}_{2}$ fixation could be the sensitivity of the BoB OMZ diazotrophs to $\mathrm{O}_{2}$ as opposed to the relative $\mathrm{O}_{2}$ tolerance of cyanobacterial $\mathrm{N}_{2}$ fixers. We identified $\mathrm{BoB}$ diazotrophs closely related to cultivated $\mathrm{N}_{2}$ fixers, including Vibrio diazotrophicus and Desulfonema limicola, which fix $\mathrm{N}_{2}$ only under strictly anaerobic conditions (Urdaci et al., 1988; Bertics et al., 2013; Gier et al., 2016). Further, communities of diazotrophs from other OMZs highly similar to the BoB diazotroph community were described to transcribe their nifH gene and to actively fix $\mathrm{N}_{2}$ only under strictly anoxic or anoxic-sulfidic conditions (Löscher et al., 2016, 2014; Jayakumar et al., 2012, 2017) and are unable to fix $\mathrm{N}_{2}$ in the presence of even minimal concentrations of $\mathrm{O}_{2}$ (reviewed in Bombar et al., 2016). $\mathrm{N}_{2}$ fixation in our samples (Table 2) may therefore be directly inhibited by the detected traces of $\mathrm{O}_{2}$. Thus, our data suggest that even only nanomolar $\mathrm{O}_{2}$ concentrations such as those present in the $\mathrm{BoB}$ may prevent non-phototrophic $\mathrm{N}_{2}$ fixers from actively fixing $\mathrm{N}_{2}$, which could ultimately limit the supply of new nitrogen to the BoB.

\subsection{Role of $\mathrm{Fe}$ and mesoscale activities (eddies)}

The high iron $(\mathrm{Fe})$ requirement of $\mathrm{N}_{2}$-fixing microbes $(60$ times higher compared to other marine organisms; Gruber and Galloway, 2008) limits $\mathrm{N}_{2}$ fixation in large parts of the ocean (Moore et al., 2013). However, eolian Fe fluxes to surface waters of the southern BoB were estimated to be comparable to those detected underneath Saharan dust plumes in the Atlantic ( $290 \pm 70 \mu \mathrm{mol} \mathrm{m}^{-2} \mathrm{yr}^{-1}$; Grand et al., 2015a). Indeed, dissolved $\mathrm{Fe}(\mathrm{dFe})$ accumulates in the $\mathrm{BoB} \mathrm{OMZ}$, reaching comparably high concentrations of up to $1.5 \mathrm{nM}$ (Grand et al., 2015b; Chinni et al., 2019). In surface waters, $\mathrm{dFe}$ concentrations were described to range from $0.4 \mathrm{nM}$ in the area of the cruise to up to $0.5 \mathrm{nM}$ towards the north of the $\mathrm{BoB}$, with increasing concentrations coinciding with decreasing salinity north of $15^{\circ} \mathrm{N}$ (Grand et al., 2015a, b; Chinni et al., 2019). While the reported Fe concentrations do not indicate $\mathrm{Fe}$ limitation of $\mathrm{N}_{2}$ fixation in the $\mathrm{OMZ}$, surface primary production and $\mathrm{N}_{2}$ fixation may be limited by any other micronutrient. Indication for such a limitation can be derived from eddy-induced Ekman pumping; mesoscale dynamics and the summer monsoon current have been shown to trigger plankton blooms with high productivity (Jyothibabu et al., 2015; Vinayachandran and Mathew, 2003; Chen et al., 2013; Fernandes et al., 2009), possibly induced by upwelling of certain nutrients to surface waters. Besides locally increasing surface water chlorophyll concentrations, erosion of the strong stratification and subsequent nutrient input to surface waters result in a change of phytoplankton size class (Prasanna Kumar et al., 2004). While usually smaller phytoplankton dominate the primary producer pool $(60 \%-95 \%$ of the total chlorophyll), the contribution of larger phytoplankton has been observed to double in the regions influenced by the summer monsoon current and in mesoscale eddies, which impacts the vertical organic carbon flux in the BoB temporally and locally (Jyothibabu et al., 2015; Prasanna Kumar et al., 2004; Huete-Ortega et al., 2010; Gomes et al., 2016). The resulting increase in organic matter production, the modified composition of organic matter (i.e., production fresh and labile particulate organic matter - POM), a faster export, and subsequent respiration could promote anoxic $\mathrm{OMZ}$ conditions in the $\mathrm{BoB}$. This may subsequently allow for $\mathrm{O}_{2}$ sensitive processes to take place, which may include $\mathrm{N}_{2}$ fixation and nitrogen loss processes (Johnson et al., 2019), locally or regionally. Rapid changes in dissolved $\mathrm{O}_{2}$ induced by increased surface productivity and organic matter export were reported in the context of mesoscale water mass dynamics in the BoB (Johnson et al., 2019) and also in other eddy systems in the Atlantic, which showed rapid $\mathrm{O}_{2}$ exhaustion in otherwise oxic waters (Fiedler et al., 2016; Löscher et al., 2015). Episodes of increased biological productivity have also been reported from the $\mathrm{BoB}$ during both the presouthwest monsoon and northeast monsoon (Kumar et al., 2004). Under those scenarios, large parts of the BoB's surface waters exhibited a strong $p \mathrm{CO}_{2}$ undersaturation com- 

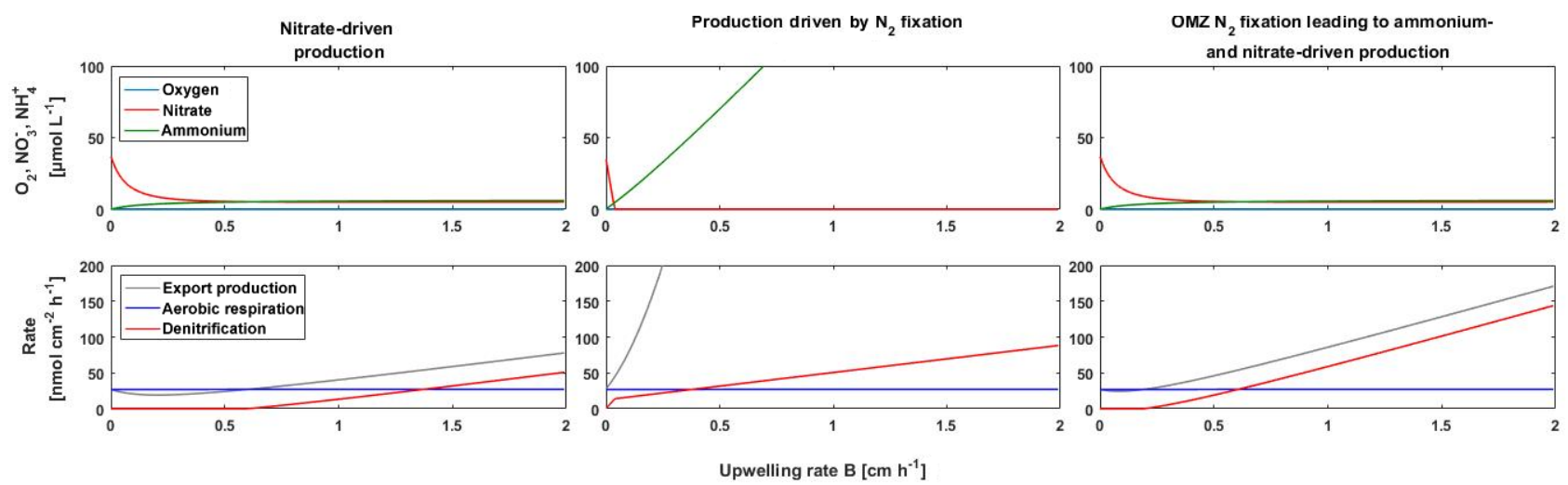

Figure 6. Model of the response of the BoB OMZ to a weaker stratification corresponding to increased upwelling in this model under a non- $\mathrm{N}_{2}$ fixation scenario with nitrate-driven production, photic-zone primary production dependent on $\mathrm{N}_{2}$ fixation, and a scenario of $\mathrm{N}_{2}$ fixation in the OMZ, which would result in build-up of a nitrogen stock and export to the productive surface if stratification becomes weaker.

pared to the atmosphere ( $\sim 350 \mu \mathrm{atm})$, resulting in an air-sea $p \mathrm{CO}_{2}$ gradient sometimes exceeding $100 \mu \mathrm{atm}$. This gradient is explainable only by an increase in biological primary production fueled by temporal external nutrient input (Kumar et al., 2004). As Singh et al. (2012) pointed out, these high-productivity episodes cannot be explained by riverine or atmospheric deposition of nutrients alone, but upwelling or $\mathrm{N}_{2}$ fixation would be required to sustain the nitrogen demand.

\subsection{Feedbacks between $\mathrm{N}_{2}$ fixation and $\mathrm{OMZ}$ intensity}

We used a simple model to test the conditions allowing for $\mathrm{N}_{2}$ fixation in the surface waters and in the $\mathrm{OMZ}$ of the $\mathrm{BoB}$ and the interplay of $\mathrm{N}_{2}$ fixation with primary production in response to changes in stratification (i.e., upwelling). We further explored how far $\mathrm{N}_{2}$ fixation controls $\mathrm{O}_{2}$ concentrations in the BoB OMZ. We simulated nitrate-driven primary production and primary production dependent on $\mathrm{N}_{2}$ fixation, which is representative of $\mathrm{N}_{2}$ fixation in the photic zone and governed by excess phosphorus and $\mathrm{Fe}$ availability as previously used in Canfield (2006) and Boyle et al. (2013). In addition, we simulated primary production that is dependent on OMZ-associated $\mathrm{N}_{2}$ fixation, which, in contrast to the classical $\mathrm{N}_{2}$ fixation scenario, is independent of a Redfieldbased nitrogen deficit, with $\mathrm{N}_{2}$ fixation being active as long as phosphorus and $\mathrm{Fe}$ are available in concentration $>0$ (Bombar et al., 2016; Löscher et al., 2014). One weakness of this model simulation is that it only includes $\mathrm{Fe}$ as potentially limiting nutrient for $\mathrm{N}_{2}$ fixation, which is, according to the available datasets (Grand et al., 2015b; Chinni et al., 2019), not necessarily correct but may be valid as an indicator for any other unrecognized micronutrient limitation. Consistent with the previous deep-time models of Canfield (2006) and Boyle et al. (2013), our model exercise revealed that additional nitrogen supply by $\mathrm{N}_{2}$ fixation or other external nitrogen sources would generally exhaust the remain- ing traces of $\mathrm{O}_{2}$ with increasing upwelling (Fig. 6). According to our model, this would lead to denitrification, which is in line with $\mathrm{O}_{2}$-manipulated experiments as presented in Bristow et al. (2017) and consistent with the available isotope records from the OMZ (Fig. S3). A weaker stratification (in the model depicted as increased upwelling fluxes) would have the strongest effect on oxygen exhaustion and the onset of denitrification if primary production is dependent on $\mathrm{N}_{2}$ fixation in the photic zone, followed by OMZ-located $\mathrm{N}_{2}$ fixation and lastly by nitrogen recycling. Given that OMZ regions are sites of massive nitrogen loss characterized by a nitrogen deficit in the water column (Deutsch et al., 2007), the similar diazotroph community in the OMZ paired with an absence of $\mathrm{N}_{2}$ fixation in the euphotic zone suggest that OMZassociated $\mathrm{N}_{2}$ fixation is the most likely scenario. Thus, nitrogen limited primary production in the $\mathrm{BoB}$ and in OMZs in general would be susceptible to changes in stratification, with increased upwelling of nutrient-rich waters causing $\mathrm{O}_{2}$ exhaustion. Considering the potential $\mathrm{O}_{2}$ sensitivity of $\mathrm{OMZ}$ diazotrophs based on the comparison with other OMZs, the interplay between $\mathrm{O}_{2}$ concentrations, stratification, and $\mathrm{N}_{2}$ fixation may act as a stabilizing feedback on the BoB OMZ, preventing full $\mathrm{O}_{2}$ depletion.

One factor possibly disturbing a possible stabilizing feedback is the external anthropogenic supply of nitrogen to the northern Indian Ocean. This additional nitrogen source is projected to increase over the next decades (Duce et al., 2008 ), potentially accelerating primary production in the future ocean, including the BoB. An atmospheric input in the range of 1.1 (model based) to $1.6 \mathrm{Tg} \mathrm{Nyr}^{-1}$ (observation based) has been reported, which will likely increase in the future (Suntharalingam et al., 2019). This additional nitrogen fertilization would cause the same effect as $\mathrm{N}_{2}$ fixation in our model, thus exhausting the present traces of $\mathrm{O}_{2}$ in the OMZ rapidly. Until an increased supply of atmospheric or riverine nitrogen becomes significant, changes in water column stratification, however, likely impose the strongest control on $\mathrm{N}_{2}$ 
fixation and primary production and thus on respiration, nitrogen loss processes, and ultimately on the $\mathrm{O}_{2}$ status of the $\mathrm{OMZ}$ in the BoB.

\section{Conclusion}

We detected a diazotrophic community similar to those from other OMZ regions; however, we could not obtain consistent evidence for active $\mathrm{N}_{2}$ fixation in the BoB. Coming back to our original question of whether there is $\mathrm{N}_{2}$ fixation in the $\mathrm{BoB}$, our data suggest that the answer is no. In other OMZs, $\mathrm{N}_{2}$ fixation has been observed to largely vary temporally and spatially, but never reaching rates comparable to oligotrophic open ocean systems such as the Pacific gyres. Episodes of $\mathrm{N}_{2}$ fixation, however, could be induced by changes in water mass dynamics or riverine- or atmospheric-nutrient input. Resulting increased $\mathrm{N}_{2}$ fixation and primary production would possibly lead to $\mathrm{O}_{2}$ exhaustion in the $\mathrm{BoB}$, which otherwise does not become fully anoxic.

Previous observations describing the absence of nitrogen loss processes in the BoB were explained by the remaining traces of $\mathrm{O}_{2}$ (Bristow et al., 2017) and possibly by a nitrogen deficiency relative to carbon in the organic matter pool. While we acknowledge that our dataset represents only a snapshot of the BoB's biogeochemical setting, our observations may help in predicting the future development of $\mathrm{N}_{2}$ fixation in the BoB and of the BoB OMZ with regard to increased atmospheric dust deposition and ocean fertilization (Duce et al., 2008), altered ocean circulation patterns (Yeh et al., 2009), and deoxygenation of the ocean as a consequence of global warming (Schmidtko et al., 2017; Stramma et al., 2008).

Code and data availability. Sequence data are available from GenBank (submission ID 2245434) and from NCBI's sequence read archive (accession number SRR9696254). The model code and other biogeochemical data are available from the PANGAEA database (Boyle, 2019, https://doi.pangaea.de/10.1594/PANGAEA. 905498; Löscher et al., 2019, https://doi.pangaea.de/10.1594/ PANGAEA.905496).

Supplement. The supplement related to this article is available online at: https://doi.org/10.5194/bg-17-851-2020-supplement.

Author contributions. CRL analyzed the data with WM. CRL ran the model simulations and wrote the paper, with substantial contributions from all co-authors.
Competing interests. The authors declare that they have no conflict of interest.

Special issue statement. This article is part of the special issue "Ocean deoxygenation: drivers and consequences - past, present and future (BG/CP/OS inter-journal SI)". It is not associated with a conference.

Acknowledgements. We thank the captain and crew of the ORV Sagar Kanya for their support during sampling. We especially thank the Ministry of Earth Sciences (MoES), India, for funding the research through the SIBER (INDIA) project GAP2425 and for making ORV Sagar Kanya available for this work. We thank Julian Dekaezemacker and Laura Piepgras for sampling on board, for providing nitrogen and carbon fixation rates, and for helpful comments on the dataset and Richard Boyle for providing the backbone model. We thank Laura Bristow for helpful comments on an earlier version of the paper, and we acknowledge Erik Laursen for technical assistance, Cameron Callbeck and Gaute Lavik for sampling, and Alexander Treusch and Michael Forth for providing access to subsamples for molecular analysis. We further thank Gerd Krahmann for help with the analysis of fluorescence data from the CTD. This study was supported by the Horizon 2020 program of the European Union (NITROX; grant no. 704272 to Carolin R. Löscher) and the Max Planck Society. Further funding was received from Villum Fonden (grant no. 16518; Donald E. Canfield) and the German Research Foundation in the frameworks of the Cluster of Excellence "The Future Ocean" and the Collaborative Research Center SFB754.

Financial support. This research has been supported by the European Commission, Horizon 2020 (NITROX; grant no. 704272); the Villum Fonden (grant no. 16518); the Collaborative Research Center (grant no. SFB754); the German Research Foundation (DFG); and the Max Planck Society.

Review statement. This paper was edited by Clare Woulds and reviewed by two anonymous referees.

\section{References}

Andersson, B., Sundbäck, K., Hellman, M., Hallin, S., and Alsterberg, C.: Nitrogen fixation in shallow-water sediments: Spatial distribution and controlling factors, Limnol. Oceanogr., 59, 1932-1944, 2014.

Angel, R., Nepel, M., Panhölzl, C., Schmidt, H., Herbold, C. W., Eichorst, S. A., and Woebken, D.: Evaluation of Primers Targeting the Diazotroph Functional Gene and Development of NifMAP - A Bioinformatics Pipeline for Analyzing nifH Amplicon Data, Front. Microbiol., 9, 703-703, https://doi.org/10.3389/fmicb.2018.00703, 2018.

Benitez-Nelson, C.: The biogeochemical cycling of phosphorus in marine systems, 109-135 pp., 2000. 
Bertics, V. J., Löscher, C. R., Salonen, I., Dale, A. W., Gier, J., Schmitz, R. A., and Treude, T.: Occurrence of benthic microbial nitrogen fixation coupled to sulfate reduction in the seasonally hypoxic Eckernförde Bay, Baltic Sea, Biogeosciences, 10, 1243-1258, https://doi.org/10.5194/bg-10-1243-2013, 2013.

Bhaskar, J., Nagappa, R., Gauns, M., and Fernandes, V.: Preponderance of a few diatom species among the highly diverse microphytoplankton assemblages in the Bay of Bengal, 63-75 pp., 2007.

Bombar, D., Paerl, R. W., and Riemann, L.: Marine Non-Cyanobacterial Diazotrophs: Moving beyond Molecular Detection, Trends Microbiol., 24, 916-927, https://doi.org/10.1016/j.tim.2016.07.002, 2016.

Bonnet, S., Dekaezemacker, J., Turk-Kubo, K. A., Moutin, T., Hamersley, R. M., Grosso, O., Zehr, J. P., and Capone, D. G.: Aphotic $\mathrm{N}_{2}$ Fixation in the Eastern Tropical South Pacific Ocean, PlosOne, 8, e81265, https://doi.org/10.1371/journal.pone.0081265, 2013.

Boyle, R. A.: Code for ancient ocean 5 box model on euxinic/ferruginous balance and the nitrogen cycle. PANGAEA, https://doi.pangaea.de/10.1594/PANGAEA.905498, dataset in review, 2019.

Boyle, R. A., Clark, J. R., Poulton, S. W., Shields-Zhou, G., Canfield, D. E., and Lenton, T. M.: Nitrogen cycle feedbacks as a control on euxinia in the mid-Proterozoic ocean, Nat. Commun., 4, 1533, https://doi.org/10.1038/ncomms2511, 2013.

Bristow, L. A., Callbeck, C. M., Larsen, M., Altabet, M. A., Dekaezemacker, J., Forth, M., Gauns, M., Glud, R. N., Kuypers, M. M. M., Lavik, G., Milucka, J., Naqvi, S. W. A., Pratihary, A., Revsbech, N. P., Thamdrup, B., Treusch, A. H., and Canfield, D. E.: $\mathrm{N}_{2}$ production rates limited by nitrite availability in the Bay of Bengal oxygen minimum zone, Nat. Geosci., 10, 24-29, https://doi.org/10.1038/ngeo2847, 2017.

Canfield, D. E.: Models of oxic respiration, denitrification and sulfate reduction in zones of coastal upwelling, Geochim. Cosmochim. Ac., 70, 5753-5765, 2006.

Chang, B. X., Jayakumar, A., Widner, B., Bernhardt, P., Mordy, C. W., Mulholland, M. R., and Ward, B. B.: Low rates of dinitrogen fixation in the eastern tropical South Pacific, Limnol. Oceanogr., 64, 1913-1923, https://doi.org/10.1002/lno.11159, 2019.

Chavez, F. P. and Messié, M.: A comparison of Eastern Boundary Upwelling Ecosystems, Prog. Oceanogr., 83, 80-96, 2009.

Chavez, F. P., Buck, K. R., Service, S. K., Newton, J., and Barber, R. T.: Phytoplankton variability in the central and eastern tropical Pacific, Deep-Sea Res. Pt. II, 43, 835-870, https://doi.org/10.1016/0967-0645(96)00028-8, 1996.

Chen, X., Pan, D., Bai, Y., He, X., Chen, C.-T. A., and Hao, Z.: Episodic phytoplankton bloom events in the Bay of Bengal triggered by multiple forcings, Deep-Sea Res. Pt. I, 73, 17-30, https://doi.org/10.1016/j.dsr.2012.11.011, 2013.

Chinni, V., Singh, S. K., Bhushan, R., Rengarajan, R., and Sarma, V. V. S. S.: Spatial variability in dissolved iron concentrations in the marginal and open waters of the Indian Ocean, Marine Chem., 208, 11-28, https://doi.org/10.1016/j.marchem.2018.11.007, 2019

Christiansen, C. F. and Loescher, C. R.: Facets of diazotrophy in the OMZ off Peru revisited: what we could not see from a single marker gene approach, bioRxiv, 558072, https://doi.org/10.1101/558072, 2019.
Dähnke, K. and Thamdrup, B.: Nitrogen isotope dynamics and fractionation during sedimentary denitrification in Boknis Eck, Baltic Sea, Biogeosciences, 10, 3079-3088, https://doi.org/10.5194/bg-10-3079-2013, 2013.

Dekaezemacker, J., Bonnet, S., Grosso, O., Moutin, T., Bressac, M., and Capone, D. G.: Evidence of active dinitrogen fixation in surface waters of the eastern tropical South Pacific during El Nino and La Nina events and evaluation of its potential nutrient controls, Global Biogeochem. Cycles, 27, 768-779, https://doi.org/10.1002/gbc.20063, 2013.

DeSantis, T. Z., Hugenholtz, P., Larsen, N., Rojas, M., Brodie, E. L., Keller, K., Huber, T., Dalevi, D., Hu, P., and Andersen, G. L.: Greengenes, a chimera-checked 16S rRNA gene database and workbench compatible with ARB, Appl. Environ. Microbiol., 72, 5069-5072, https://doi.org/10.1128/aem.03006-05, 2006.

Deutsch, C., Sarmiento, J. L., Sigman, D. M., Gruber, N., and Dunne, J. P.: Spatial coupling of nitrogen inputs and losses in the ocean, Nature, 445, 163-167, https://doi.org/10.1038/nature05392, 2007.

Duce, R. A., LaRoche, J., Altieri, K., Arrigo, K. R., Baker, A. R., Capone, D. G., Cornell, S., Dentener, F., Galloway, J., Ganeshram, R. S., Geider, R. J., Jickells, T., Kuypers, M. M., Langlois, R., Liss, P. S., Liu, S. M., Middelburg, J. J., Moore, C. M., Nickovic, S., Oschlies, A., Pedersen, T., Prospero, J., Schlitzer, R., Seitzinger, S., Sorensen, L. L., Uematsu, M., Ulloa, O., Voss, M., Ward, B., and Zamora, L.: Impacts of atmospheric anthropogenic nitrogen on the open ocean, Science, 320, 893-897, https://doi.org/10.1126/science.1150369, 2008.

Farnelid, H., Andersson, A. F., Bertilsson, S., Al-Soud, W. A., Hansen, L. H., Sørensen, S., Steward, G. F., Hagström, A., and Riemann, L.: Nitrogenase Gene Amplicons from Global Marine Surface Waters Are Dominated by Genes of Non-Cyanobacteria, PLoS One, 6, e19223, https://doi.org/10.1371/journal.pone.0019223, 2011.

Farnelid, H., Bentzon-Tilia, M., Andersson, A. F., Bertilsson, S., Jost, G., Labrenz, M., Juergens, K., and Riemann, L.: Active nitrogen-fixing heterotrophic bacteria at and below the chemocline of the central Baltic Sea, Isme J., 7, 1413-1423, https://doi.org/10.1038/ismej.2013.26, 2013.

Fernandes, L., Bhosle, N. B., Matondkar, S. G. P., and Bhushan, R.: Seasonal and spatial distribution of particulate organic matter in the Bay of Bengal, J. Marine Syst., 77, 137-147, https://doi.org/10.1016/j.jmarsys.2008.12.002, 2009

Fernandez, C., Farias, L., and Ulloa, O.: Nitrogen Fixation in Denitrified Marine Waters, Plos One, 6, e20539, https://doi.org/10.1371/journal.pone.0020539, 2011.

Fiedler, B., Grundle, D. S., Schütte, F., Karstensen, J., Löscher, C. R., Hauss, H., Wagner, H., Loginova, A., Kiko, R., Silva, P., Tanhua, T., and Körtzinger, A.: Oxygen utilization and downward carbon flux in an oxygen-depleted eddy in the eastern tropical North Atlantic, Biogeosciences, 13, 5633-5647, https://doi.org/10.5194/bg-13-5633-2016, 2016.

Fulweiler, R. W., Nixon, S. W., Buckley, B. A., and Granger, S. L.: Reversal of the net dinitrogen gas flux in coastal marine sediments, Nature, 448, 180, https://doi.org/10.1038/nature05963, 2007.

Gaby, J. C. and Buckley, D. H.: A comprehensive aligned nifH gene database: a multipurpose tool for studies of 
nitrogen-fixing bacteria, Database, Oxford, 2014, bau001, https://doi.org/10.1093/database/bau001, 2014.

Gaby, J. C., Rishishwar, L., Valderrama-Aguirre, L. C., Green, S. J., Valderrama-Aguirre, A., Jordan, I. K., and Kostka, J. E.: Diazotroph Community Characterization via a HighThroughput nifH Amplicon Sequencing and Analysis Pipeline, Appl. Environ. Microbiol., 84, e01512-01517, https://doi.org/10.1128/aem.01512-17, 2018.

Gaye-Haake, B., Lahajnar, N., Emeis, K.-C., Unger, D., Rixen, T., Suthhof, A., Ramaswamy, V., Schulz, H., Paropkari, A. L., Guptha, M. V. S., and Ittekkot, V.: Stable nitrogen isotopic ratios of sinking particles and sediments from the northern Indian Ocean, Marine Chem., 96, 243-255, 2005.

Gier, J., Sommer, S., Löscher, C. R., Dale, A. W., Schmitz, R. A., and Treude, T.: Nitrogen fixation in sediments along a depth transect through the Peruvian oxygen minimum zone, Biogeosciences, 13, 4065-4080, https://doi.org/10.5194/bg-134065-2016, 2016.

Gier, J., Löscher, C. R., Dale, A. W., Sommer, S., Lomnitz, U., and Treude, T.: Benthic Dinitrogen Fixation Traversing the Oxygen Minimum Zone Off Mauritania (NW Africa), Front. Marine Sci., 4, 390, https://doi.org/10.3389/fmars.2017.00390, 2017.

Giovannoni, S. J., Rappe, M. S., Vergin, K. L., and Adair, N. L.: 16S rRNA genes reveal stratified open ocean bacterioplankton populations related to the Green Non-Sulfur bacteria, P. Natl. Acad. Sci. USA, 93, 7979-7984, 1996.

Goebel, N. L., Turk, K. A., Achilles, K. M., Paerl, R., Hewson, I., Morrison, A. E., Montoya, J. P., Edwards, C. A., and Zehr, J. P.: Abundance and distribution of major groups of diazotrophic cyanobacteria and their potential contribution to $\mathrm{N}_{2}$ fixation in the tropical Atlantic Ocean, Environ. Microbiol., 12, 3272-3289, https://doi.org/10.1111/j.1462-2920.2010.02303.x, 2010.

Gomes, H. do R., deRada, S., Goes, J. I., and Chai, F.: Examining features of enhanced phytoplankton biomass in the Bay of Bengal using a coupled physical-biological model, J. Geophys. Res.-Ocean., 121, 5112-5133, https://doi.org/10.1002/2015JC011508, 2016.

Grand, M. M., Measures, C. I., Hatta, M., Hiscock, W. T., Buck, C. S., and Landing, W. M.: Dust deposition in the eastern Indian Ocean: The ocean perspective from Antarctica to the Bay of Bengal, Global Biogeochem. Cycles, 29, 357-374, https://doi.org/10.1002/2014gb004898, 2015a.

Grand, M. M., Measures, C. I., Hatta, M., Hiscock, W. T., Landing, W. M., Morton, P. L., Buck, C. S., Barrett, P. M., and Resing, J. A.: Dissolved $\mathrm{Fe}$ and $\mathrm{Al}$ in the upper $1000 \mathrm{~m}$ of the eastern Indian Ocean: A high-resolution transect along $95^{\circ} \mathrm{E}$ from the Antarctic margin to the Bay of Bengal, Global Biogeochem. Cycles, 29, 375-396, https://doi.org/10.1002/2014gb004920, 2015b.

Grasshoff, G., Kremling, K., and Erhardt, M. : Methods of seawater analysis, 3rd ed., Wiley VCH, Weinheim, 1999.

Grosskopf, T., Mohr, W., Baustian, T., Schunck, H., Gill, D., Kuypers, M. M. M., Lavik, G., Schmitz, R. A., Wallace, D. W. R., and LaRoche, J.: Doubling of marine dinitrogen-fixation rates based on direct measurements, Nature, 488, 361-364, https://doi.org/10.1038/nature11338, 2012.

Gruber, N. and Galloway, J. N.: An Earth-system perspective of the global nitrogen cycle, Nature, 451, 293-296, 2008.

Halm, H., Lam, P., Ferdelman, T. G., Lavik, G., Dittmar, T., LaRoche, J., D'Hondt, S., and Kuypers, M. M. M.: Heterotrophic organisms dominate nitrogen fixation in the South Pacific Gyre, Isme J., 6, 1238-1249, https://doi.org/10.1038/ismej.2011.182, 2012.

Hamersley, M. R., Turk, K. A., Leinweber, A., Gruber, N., Zehr, J. P., Gunderson, T., and Capone, D. G.: Nitrogen fixation within the water column associated with two hypoxic basins in the Southern California Bight, Aquatic Microb. Ecol., 63, 193, https://doi.org/10.3354/ame01494, 2011.

Hegde, S.: Studies on phytoplankton community with reference to diatoms, $\mathrm{PhD}$, National Institute of Oceanography, Goa University, 137 pp., 2010.

Huete-Ortega, M., Marañón, E., Varela, M., and Bode, A.: General patterns in the size scaling of phytoplankton abundance in coastal waters during a 10-year time series, J. Plankton Res., 32, 1-14, https://doi.org/10.1093/plankt/fbp104, 2010.

Jayakumar, A., Al-Rshaidat, M. M. D., Ward, B. B., and Mulholland, M. R.: Diversity, distribution, and expression of diazotroph nifH genes in oxygen-deficient waters of the Arabian Sea, Fems Microbiol. Ecol., 82, 597-606, https://doi.org/10.1111/j.15746941.2012.01430.x, 2012.

Jayakumar, A., Chang, B. X., Widner, B., Bernhardt, P., Mulholland, M. R., and Ward, B. B.: Biological nitrogen fixation in the oxygen-minimum region of the eastern tropical North Pacific ocean, ISME J., 11, 2356-2367, https://doi.org/10.1038/ismej.2017.97, 2017.

Johnson, K. S., Riser, S. C., and Ravichandran, M.: Oxygen Variability Controls Denitrification in the Bay of Bengal Oxygen Minimum Zone, Geophys. Res. Lett., 46, 804-811, https://doi.org/10.1029/2018gl079881, 2019.

Jyothibabu, R., Madhu, N. V., Maheswaran, P. A., C R, A., Thangavel, B., Nair, K. K. C., and Achuthankutty, C. T.: Environmentally-related seasonal variation in symbiotic associations of heterotrophic dinoflagellates with cyanobacteria in the western Bay of Bengal, Symbiosis, 42, 51-58, 2006.

Jyothibabu, R., Vinayachandran, P. N., Madhu, N. V., Robin, R. S., Karnan, C., Jagadeesan, L., and Anjusha, A.: Phytoplankton size structure in the southern Bay of Bengal modified by the Summer Monsoon Current and associated eddies: Implications on the vertical biogenic flux, J. Marine Syst., 143, 98-119, https://doi.org/10.1016/j.jmarsys.2014.10.018, 2015.

Knapp, A. N., Casciotti, K. L., Berelson, W. M., Prokopenko, M. G., and Capone, D. G.: Low rates of nitrogen fixation in eastern tropical South Pacific surface waters, P. Natl. Acad. Sci. USA, 113, 4398-4403, https://doi.org/10.1073/pnas.1515641113, 2016.

Konwar, K. M., Hanson, N. W., Pagé, A. P., and Hallam, S. J.: MetaPathways: a modular pipeline for constructing pathway/genome databases from environmental sequence information, BMC Bioinformatics, 14, 202, https://doi.org/10.1186/1471-2105-14202, 2013.

Krishna, M. S., Prasad, M. H. K., Rao, D. B., Viswanadham, R., Sarma, V. V. S. S., and Reddy, N. P. C.: Export of dissolved inorganic nutrients to the northern Indian Ocean from the Indian monsoonal rivers during discharge period, Geochim. Cosmochim. Ac., 172, 430-443, https://doi.org/10.1016/j.gca.2015.10.013, 2016.

Kumar, S., Ramesh, R., Sardesai, S., and Sheshshayee, M. S.: High new production in the Bay of Bengal: Possible causes and implications, Geophys. Res. Lett., 31, L18304, https://doi.org/10.1029/2004GL021005, 2004. 
Kumar, S., Stecher, G., and Tamura , K.: MEGA7: Molecular Evolutionary Genetics Analysis version 7.0 for bigger datasets, Mol. Biol. Evol., 33, 1870-1874 2016.

Kumar, S. P., Muraleedharan, P. M., Prasad, T. G., Gauns, M., Ramaiah, N., de Souza, S. N., Sardesai, S., and Madhupratap, M.: Why is the Bay of Bengal less productive during summer monsoon compared to the Arabian Sea?, Geophys. Res. Lett., 29, 2235, https://doi.org/10.1029/2002GL016013, 2002.

Kumar, S. P., Narvekar, J., Murukesh, N., Nagappa, R., Sardessai, S., Gauns, M., Fernandes, V., and Bhaskar, J.: Is the biological productivity in the Bay of Bengal light limited?, Curr. Sci., 98, 1331-1339, 2010.

Loisel, H., Vantrepotte, V., Jamet, C., and Dinh Ngoc, D.: Challenges and New Advances in Ocean Color Remote Sensing of Coastal Waters, in: Earth and Planetary Sciences, Oceanography and Atmospheric Sciences, "Topics in Oceanography", edited by: Zambianchi, E., INTECH, London, UK, 2013.

Longhurst, A. R., Sathyendrenath, S., Platt, T., Caverhill, C., and Res, J. P.: An estimat ion of global primary product ion in the ocean from satellite radiometer data, J. Plankton Res., 17, 1245$1271,1995$.

Lorenzoni, L., Toro-Farmer, G., Varela, R., Guzman, L., Rojas, J., Montes, E., and Muller-Karger, F.: Characterization of phytoplankton variability in the Cariaco Basin using spectral absorption, taxonomic and pigment data, Remote Sens. Environ., 167, 259-268, https://doi.org/10.1016/j.rse.2015.05.002, 2015.

Löscher, C. R., Großkopf, T., Desai, F., Gill, D., Schunck, H., Croot, P., Schlosser, C., Neulinger, S. C., Lavik, G., Kuypers, M. M. M., LaRoche, J., and Schmitz, R. A.: Facets of diazotrophy in the oxygen minimum zone off Peru, ISME J., 8, 2180-2192, https://doi.org/10.1038/ismej.2014.71, 2014.

Löscher, C. R., Fischer, M. A., Neulinger, S. C., Fiedler, B., Philippi, M., Schütte, F., Singh, A., Hauss, H., Karstensen, J., Körtzinger, A., Künzel, S., and Schmitz, R. A.: Hidden biosphere in an oxygen-deficient Atlantic open-ocean eddy: future implications of ocean deoxygenation on primary production in the eastern tropical North Atlantic, Biogeosciences, 12, 7467-7482, https://doi.org/10.5194/bg-12-7467-2015, 2015.

Löscher, C. R., Bourbonnais, A., Dekaezemacker, J., Charoenpong, C. N., Altabet, M. A., Bange, H. W., Czeschel, R., Hoffmann, C., and Schmitz, R.: $\mathrm{N}_{2}$ fixation in eddies of the eastern tropical South Pacific Ocean, Biogeosciences, 13, 2889-2899, https://doi.org/10.5194/bg-13-2889-2016, 2016.

Löscher, C. R., Mohr, W., Bange, H. W., and Canfield, D. E.: Nitrogen and Carbon fixation in the Bay of Bengal, PANGAEA, https: //doi.pangaea.de/10.1594/PANGAEA.905496, dataset in review, 2019.

Luo, Y.-W., Doney, S. C., Anderson, L. A., Benavides, M., BermanFrank, I., Bode, A., Bonnet, S., Boström, K. H., Böttjer, D., Capone, D. G., Carpenter, E. J., Chen, Y. L., Church, M. J., Dore, J. E., Falcón, L. I., Fernández, A., Foster, R. A., Furuya, K., Gómez, F., Gundersen, K., Hynes, A. M., Karl, D. M., Kitajima, S., Langlois, R. J., LaRoche, J., Letelier, R. M., Marañón, E., McGillicuddy Jr., D. J., Moisander, P. H., Moore, C. M., Mouriño-Carballido, B., Mulholland, M. R., Needoba, J. A., Orcutt, K. M., Poulton, A. J., Rahav, E., Raimbault, P., Rees, A. P., Riemann, L., Shiozaki, T., Subramaniam, A., Tyrrell, T., Turk-Kubo, K. A., Varela, M., Villareal, T. A., Webb, E. A., White, A. E., Wu, J., and Zehr, J. P.: Database of diazotrophs in global ocean: abundance, biomass and nitrogen fixation rates, Earth Syst. Sci. Data, 4, 47-73, https://doi.org/10.5194/essd-447-2012, 2012.

Mahadevan, A.: The Impact of Submesoscale Physics on Primary Productivity of Plankton, Annu. Rev. Mar. Sci., 8, 161-184, https://doi.org/10.1146/annurev-marine-010814-015912, 2016.

Martínez-Pérez, C., Mohr, W., Löscher, C. R., Dekaezemacker, J., Littmann, S., Yilmaz, P., Lehnen, N., Fuchs, B. M., Lavik, G., Schmitz, R. A., LaRoche, J., and Kuypers, M. M. M.: The small unicellular diazotrophic symbiont, UCYN-A, is a key player in the marine nitrogen cycle, Nat. Microbiol., 1, 16163 , https://doi.org/10.1038/nmicrobiol.2016.163, 2016.

Mazard, S. L., Fuller, N. J., Orcutt, K. M., Bridle, O., and Scanlan, D. J.: PCR Analysis of the Distribution of Unicellular Cyanobacterial Diazotrophs in the Arabian Sea, Appl. Environ. Microb., 70, 7355-7364, https://doi.org/10.1128/aem.70.12.73557364.2004, 2004.

McCreary, J. P., Yu, Z., Hood, R. R., Vinaychandran, P. N., Furue, R., Ishida, A., and Richards, K. J.: Dynamics of the IndianOcean oxygen minimum zones, Prog. Oceanogr., 112-113, 1537, https://doi.org/10.1016/j.pocean.2013.03.002, 2013.

Mohr, W., Großkopf, T., Wallace, D. W. R., and LaRoche, J.: Methodological Underestimation of Oceanic Nitrogen Fixation Rates, PLoS ONE, 5, e12583, https://doi.org/10.1371/journal.pone.0012583, 2010.

Moore, C. M., Mills, M. M., Arrigo, K. R., Berman-Frank, I., Bopp, L., Boyd, P. W., Galbraith, E. D., Geider, R. J., Guieu, C., Jaccard, S. L., Jickells, T. D., La Roche, J., Lenton, T. M., Mahowald, N. M., Maranon, E., Marinov, I., Moore, J. K., Nakatsuka, T., Oschlies, A., Saito, M. A., Thingstad, T. F., Tsuda, A., and Ulloa, O.: Processes and patterns of oceanic nutrient limitation, Nat. Geosci., 6, 701-710, https://doi.org/10.1038/ngeo1765, 2013.

Mulholland, M. R. and Capone, D. G.: Dinitrogen Fixation in the Indian Ocean, in: Indian Ocean Biogeochemical Processes and Ecological Variability, edited by: Wiggert, J. D., Hood, R. R., Naqvi, S. W. A., Brink, K. H., and Smith, S. L., American Geophysical Union Washington, DC, USA, 167-186, 2009.

Naqvi, S. W. A.: The Indian Ocean, in: Nitrogen in the Marine Environment, edited by: Capone, D. G., Elsevier, Burlington, Mass., USA, 631-681, 2008.

Naqvi, S. W. A., Naik, H., D’Souza, W., Narvekar, P. V., Paropkari, A. L., and Bange, H. W.: Carbon and nitrogen fluxes in the North Indian Ocean, in: Carbon and nutrient fluxes in continental margins: A global synthesis, edited by: Liu, K.-K., Atkinson, L., Quiñones, R., and Talaue-McManus, L., Springer-Verlag, New York, 180-191, 2010.

Paulmier, A. and Ruiz-Pinto, D.: Oxygen minimum zones in the modern ocean, Prog. Oceanogr., 80, 113-128, https://doi.org/10.1016/j.pocean.2008.08.001, 2009.

Prasanna Kumar, S., Nuncio, M., Narvekar, J., Kumar, A., Sardesai, S., de Souza, S. N., Gauns, M., Ramaiah, N., and Madhupratap, M.: Are eddies nature's trigger to enhance biological productivity in the Bay of Bengal?, Geophys. Res. Lett., 31, L07309, https://doi.org/10.1029/2003GL019274, 2004.

Ramanathan, V., Ramana, M. V., Roberts, G., Kim, D., Corrigan, C., Chung, C., and Winker, D.: Warming trends in Asia amplified by brown cloud solar absorption, Nature, 448, 575, https://doi.org/10.1038/nature06019, 2007. 
Revsbech, N. P., Larsen, L. H., Gundersen, J., Dalsgaard, T., Ulloa, O., and Thamdrup, B.: Determination of ultra-low oxygen concentrations in oxygen minimum zones by the STOX sensor, Limnol. Oceanogr. Meth., 7, 371-381, 2009.

Riemann, L., Farnelid, H., and Steward, G. F.: Nitrogenase genes in non-cyanobacterial plankton: prevalence, diversity and regulation in marine waters, Aquatic Microbial. Ecol., 61, 225-237, https://doi.org/10.3354/ame01431, 2010.

Sahu, B. K., Baliarsingh, S. K., Lotliker, A. A., Parida, C., Srichandan, S., and Sahu, K. C. J. O. S. J.: Winter thermal inversion and Trichodesmium dominance in north-western Bay of Bengal, Ocean Sci. J., 52, 301-306, https://doi.org/10.1007/s12601-0170028-1, 2017.

Sarma, V. V. S. S.: An evaluation of physical and biogeochemical processes regulating perennial suboxic conditions in the water column of the Arabian Sea, Global Biogeochem. Cycles, 16, 2921-29-11, https://doi.org/10.1029/2001GB001461, 2002.

Sathyendranath, S., Stuart, V., Nair, A., Oka, K., Nakane, T., Bouman, H., Forget, M. H., Maass, H., and Platt, T.: Carbonto-chlorophyll ratio and growth rate of phytoplankton in the sea, Mar. Ecol. Prog. Ser., 383, 73-84, 2009.

Schmidtko, S., Stramma, L., and Visbeck, M.: Decline in global oceanic oxygen content during the past five decades, Nature, 542, 335-339, https://doi.org/10.1038/nature21399, 2017.

Shetye, S., Sudhakar, M., Jena, B., and Mohan, R.: Occurrence of Nitrogen Fixing Cyanobacterium Trichodesmium under Elevated $p \mathrm{CO}_{2}$ Conditions in the Western Bay of Bengal, Int. J. Oceanogr., 2013, 8, https://doi.org/10.1155/2013/350465, 2013.

Singh, A. and Ramesh, R.: Contribution of riverine dissolved inorganic nitrogen flux to new production in the coastal northern Indian Ocean: An assessment, Int. J. Oceanogr., 2011, 983561, https://doi.org/10.1155/2011/983561, 2011.

Singh, A., Gandhi, N., and Ramesh, R.: Contribution of atmospheric nitrogen deposition to new production in the nitrogen limlited photic zone of the northern Indian Ocean, J. Geophys. Res., 117, C06004, https://doi.org/10.1029/2011JC007737, 2012.

Sohm, J. A., Webb, E. A., and Capone, D. G.: Emerging patterns of marine nitrogen fixation, Nat. Rev. Micro., 9, 499-508, 2011.

Srinivas, B. and Sarin, M. M.: Atmospheric deposition of N, $\mathrm{P}$ and $\mathrm{Fe}$ to the Northern Indian Ocean: Implications to C- and N-fixation, Sci. Total Environ., 456-457, 104-114, https://doi.org/10.1016/j.scitotenv.2013.03.068, 2013.

Stramma, L., Johnson, G. C., Sprintall, J., and Mohrholz, V.: Expanding oxygen-minimum zones in the tropical oceans, Science, 320, 655-658, https://doi.org/10.1126/science.1153847, 2008.

Subramaniam, A., Yager, P. L., Carpenter, E. J., Mahaffey, C., Björkman, K., Cooley, S., Kustka, A. B., Montoya, J. P., SanudoWilhelmy, S. A., Shipe, R., and Capone, D. G.: Amazon River enhances diazotrophy and carbon sequestration in the tropical North Atlantic Ocean, P. Natl. Acad. Sci. USA, 105, 1046010465, 2008.
Subramanian, V.: Sediment load of Indian rivers, Curr. Sci., 64, 928-930, 1993.

Suntharalingam, P., Zamora, L. M., Bange, H. W., Bikkina, S., Buitenhuis, E., Kanakidou, M., Lamarque, J.-F., Landolfi, A., Resplandy, L., Sarin, M. M., Seitzinger, S., and Singh, A.: Anthropogenic nitrogen inputs and impacts on oceanic $\mathrm{N}_{2} \mathrm{O}$ fluxes in the northern Indian Ocean: The need for an integrated observation and modelling approach, Deep-Sea Res. Pt. II, 166, 104 113, https://doi.org/10.1016/j.dsr2.2019.03.007, 2019.

Turk-Kubo, K. A., Karamchandani, M., Capone, D. G., and Zehr, J. P.: The paradox of marine heterotrophic nitrogen fixation: abundances of heterotrophic diazotrophs do not account for nitrogen fixation rates in the Eastern Tropical South Pacific, Environ. Microbiol., 16, 3095-3114, https://doi.org/10.1111/14622920.12346, 2014.

Urdaci, M. C., Stal, L. J., and Marchand, M.: Occurrence of nitrogen fixation among Vibrio spp, Arch. Microbiol., 150, 224-229, https://doi.org/10.1007/BF00407784, 1988.

Vinayachandran, P. N. and Mathew, S.: Phytoplankton bloom in the Bay of Bengal during the northeast monsoon and its intensification by cyclones, Geophys. Res. Lett., 30, 1572, https://doi.org/10.1029/2002GL016717, 2003.

Wang, W.-L., Moore, J. K., Martiny, A. C., and Primeau, F. W.: Convergent estimates of marine nitrogen fixation, Nature, 566, 205-211, https://doi.org/10.1038/s41586-019-0911-2, 2019.

White, A. E., Foster, R. A., Benitez-Nelson, C. R., Masqué, P., Verdeny, E., Popp, B. N., Arthur, K. E., and Prahl, F. G.: Nitrogen fixation in the Gulf of California and the Eastern Tropical North Pacific, Prog. Oceanogr., 109, 1-17, https://doi.org/10.1016/j.pocean.2012.09.002, 2013.

Wu, C., Kan, J., Liu, H., Pujari, L., Guo, C., Wang, X., and Sun, J.: Heterotrophic Bacteria Dominate the Diazotrophic Community in the Eastern Indian Ocean (EIO) during Pre-Southwest Monsoon, Microb. Ecol., 78, 804-819, https://doi.org/10.1007/s00248-019-01355-1, 2019.

Yeh, S.-W., Kug, J.-S., Dewitte, B., Kwon, M.-H., Kirtman, B. P., and Jin, F.-F.: El Niño in a changing climate, Nature, 461, 511, https://doi.org/10.1038/nature08316, 2009.

Zehr, J. P., Mellon, M. T., and Zani, S.: New nitrogen-fixing microorganisms detected in oligotrophic oceans by amplification of nitrogenase (nifH) genes, Appl. Environm. Microb., 64, 50675067, 1998.

Zehr, J. P., Waterbury, J. B., Turner, P. J., Montoya, J. P., Omoregie, E., Steward, G. F., Hansen, A., and Karl, D. M.: Unicellular cyanobacteria fix $\mathrm{N}_{2}$ in the subtropical North Pacific Ocean, Nature, 412, 635-638, 2001.

Zehr, J. P., Jenkins, B. D., Short, S. M., and Steward, G. F.: Nitrogenase gene diversity and microbial community structure: a cross-system comparison, Environ. Microb., 5, 539-554, 2003. 